\title{
Effect of Aluminum Addition with Nitrogen on K-Carbide Formation in Carbon- Mn Steel
}

\author{
Shahid Hussain ABRO ${ }^{1 *}$, Alidad CHANDIO ${ }^{1}$, Asif Ahmed SHAIKH ${ }^{2}$, Norbaizura NORDIN ${ }^{2}$ \\ ${ }^{1}$ NED University of Engineering \& Technology Pakistan, Department of Metallurgical Engineering, Main University Road \\ Karachi, Pakistan \\ ${ }^{2}$ Department of Science and Mathematics, Center of Diploma Studied University Tun Hussein Onn, 86400 Parit Raja \\ Batu Pahat Johor Malaysia
}

crossref http://dx.doi.org/10.5755/j02.ms.28400

Received 27 January 2021; accepted 15 March 2021

\begin{abstract}
An attempt has been made in the present research work to investigate the role and influence of chemical effect of aluminum addition in the experimental steel towards the formation of k-carbides. Two steel grades were made with and without aluminum addition by induction melting furnace and were cast to ingots. Steel A has no aluminum addition and steel B has some aluminum content. These ingots were then solution heat treated on a temperature of 1200 ' $\mathrm{C}$ for 2-hours' time and were cooled in the air. After that, they were hot rolled to drawn in plate and sheet. The small samples were cut from bulk and were then heat-treated at $800^{\circ} \mathrm{C}$ for 1 hour and quenched. Microstructure by OM and SEM was captured. In steel A there was no k-carbide present in the matrix and surprisingly in steel B, small fine k-carbides were present this was then confirmed by XRD later. OM, SEM, and TEM analysis revealed that the presence of k-carbides in steel B makes less dense. It was concluded that aluminum in conjunction with nitrogen forms the small nitride particles having a high melting point does not dissolve during the melting and casting such particles are known as AlN or aluminum nitride particles was observed by TEM along with EDS was the main reason to support the formation of k-carbides, these fine nano level kcarbides are orderly distributed in the steel matrix as was shown by XRD peaks.
\end{abstract}

Keywords: aluminum, AIN particles, k-carbides, austenite, XRD, TEM.

\section{INTRODUCTION}

Since decades ago, there was an increasing competition among the steel manufacturers for producing safe, light and economical steel on the hands, in this high challenging marketing environment of achieving those above factors as well as maintaining and economizing without sacrificing the strength, many researchers investigate the TRIP, TWIP and CHQ steels [1-5]. Strength at low weight has always been a subject of interest for every researcher [5-9]. Many research studies showed and proved that by increasing the amount of manganese and aluminum the simultaneous effect of increasing strength and decreasing density can be achieved. But on the other hand, $\mathrm{Mn}$ is supposed to be a high-cost element [10-17]. In this work increasing the amount of aluminum can decrease the density and increase the strength up to a certain level [18]. Formation of kcarbides can play a vital role to achieve strength to weight ratio but the k-carbides formation is always a challenging task in many sheets of steel $[18,21]$. One of the common methods in developing $\mathrm{k}$-carbides is by aging technique but controlling the parameters during aging treatment is so crucial that means aging technique is not always the assurance for developing such carbides in each steel grade secondly aging itself is time-consuming and added step during the research work [22-25]. The standard lattice frame work of the kappa carbides is approximately $\mathrm{a}_{0}=3.837 \times 10^{2} \mathrm{~nm}$ and that of unit cell $(\mathrm{Fe}, \mathrm{Mn}) 3 \mathrm{AlC}$ is orderly mannered face centered cubic structure. The presence of aluminum affects the overall structural framework of kappa carbide. The k-carbide plays a vital role in strengthening the steel $[25,26]$. The kappa carbide particles have been considered by many material scientists to be a responsible element for the increasing the mechanical properties of the steel $[27,28]$. However, kcarbide has different behavior at different chemical compositions and treatments which affect the properties of that steel [29]. A huge effort has been done so far on the behavior and deformation techniques of kappa-carbides in aged conditions, there is a little work has been reported so far the elements that can promote the formation of $k$ carbides so there is strong driving force for researchers working in this area that adding the alloying elements and their reaction to themselves and its effect upon formation of $\mathrm{k}$ carbides and it's interaction with nitrides is the subject of high interest [30-31]. The main focus of this research work is to study and investigate the reason of k-carbide formation in the experimental steel by means of aluminum addition along with nitrogen [32-34].

\section{MATERIALS AND EXPERIMENTAL METHOD}

Two steel grades were made with the almost the same chemical composition the only major difference was the aluminum addition in steel $\mathrm{B}$. The chemical composition of the steel A is: $\mathrm{Fe}-0.463 \mathrm{C}, 0.241 \mathrm{Si}, 0.872 \mathrm{Mn}, 0.0049 \mathrm{~N}$

\footnotetext{
* Corresponding author. Tel.: +92-21-99261261; fax: ++92-21-99261255.

E-mail address: engrabro@neduet.edu.pk (S.H. Abro)
} 
and steel B has chemical composition Fe-0.454 C, 0.255 Si $0.778 \mathrm{Mn}, 0.011 \mathrm{~N}, 0.152 \mathrm{Cr}, 0.033 \mathrm{Al}$.

Melting was performed in an induction furnace with inert atmosphere after melting both experimental steels were cast in ingots. These steel ingots were solution treated at an elevated temperature of $1200^{\circ} \mathrm{C}$ for 2 hours and for two reasons, firstly to break the as-cast structure and secondly to dissolve the insoluble second phase particles if they were present during melting and casting. The ingots were then deformed above the re-crystallization temperature of that steel by performing the hot rolling in four passes and thickness of the ingots was reduced to $20 \mathrm{~mm}$ from $100 \mathrm{~mm}$ by means of $80 \%$ reduction. The cutting of the plate was performed at $800{ }^{\circ} \mathrm{C}$ and then the steel was led to be cooled in air at room temperature. After cooling in the air both the steel $A$ and $B$ were further cut at $10 \times 10 \mathrm{~mm}$ samples. The squared samples were then immediately brought in muffle furnace and heat treated at $800{ }^{\circ} \mathrm{C}$ for 1 hour homogenizing at that temperature and was quenched. After cooling in water, samples were further cut perpendicular to the rolling direction to observe the microstructural features of both the steels. The heat-treated samples and in as hot rolled condition, un-heat-treated samples, were grind from 200 to 2200 grade emery paper. After grinding samples were polished in 0.5 alumina solution mixed with distilled water on polishing cloth made from silk after sufficient polishing samples were further polished by applying diamond paste. After polishing samples were ultrasonically cleaned in ethanol solution to remove the burse and residue of white alumina paste during the polishing then samples were washed in distilled water and dried with hot air. For observing the initial microstructure samples were etched in a solution of $4 \mathrm{gm}$ picric acid. The etching time duration was from 5 to 20 seconds, but the microstructure was not revealing, the possible reason was that, due to increasing the surface tension during quenching the etchant was not

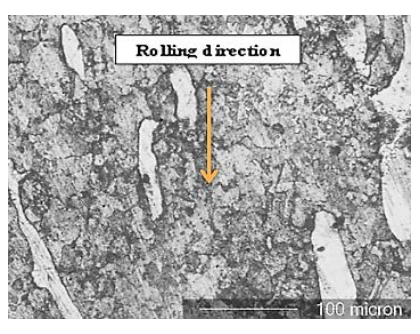

a

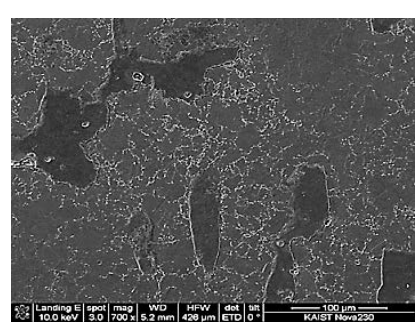

b

reacting the surface of steel samples so to increase the driving force of etching the etchant was slightly heated up to $80^{\circ} \mathrm{C}$ on a hot plate. This technique successfully revealed the microstructure. The as hot rolled microstructure of both the steels A and steel B is shown in Fig. 1.

By closely watching both the steels in heat treated condition in Fig. 2 it was found that in the steel A has coarse grain boundary network, due to lack of aluminum addition on contrary steel B has fine grain network, aluminum is present there which chemically combines together with nitrogen to form AlN particles because aluminum has good affinity with nitrogen to form AlN particles that may limit the grain Fig. $5 \mathrm{a}$ and $\mathrm{b}$ boundary mobility during deformation as a result grain network formed fine.

By investigating the microstructure morphology of heattreated steels, $\mathrm{A}$ at a temperature of $800^{\circ} \mathrm{C}$ for 1 hour, there is no precipitation at the grain boundary and also there is no small nano-sized ordered k-carbide particles are formed but on the other hand k-carbide particles are visible in steel $\mathrm{B}$ this morphology is shown in Fig. $2 \mathrm{c}$ and d.

In the steel $\mathrm{B}$ having aluminum nitride particles, the formation of kappa carbides makes the grain network finer, strong reason is that these small particles applied the pinning force to restrict the grain growth of the grains in steel B and also precipitation at the grain boundary by kappa carbides makes the structure fine consequently the grain size remains smaller and finer because the aluminum addition promotes the formation of orderly intragranular kappa carbides as shown in Fig. 4 a and b. However, this phenomenon was not observed in the steel A because such precipitation does not take place in the steel matrix due to the absence of such particles. To verify and understand the kappa carbide morphology TEM images of steel B were taken after $\mathrm{OM}$ and SEM micrographs as shown in Fig. $3 \mathrm{a}$ and $\mathrm{b}$ respectively. The images are present in both bright field and dark filed respectively.

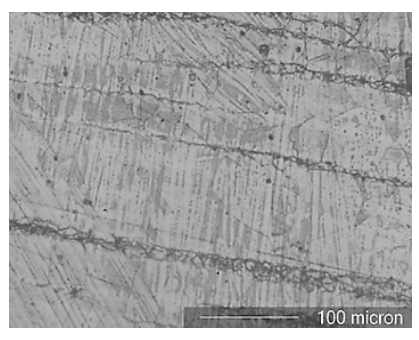

C

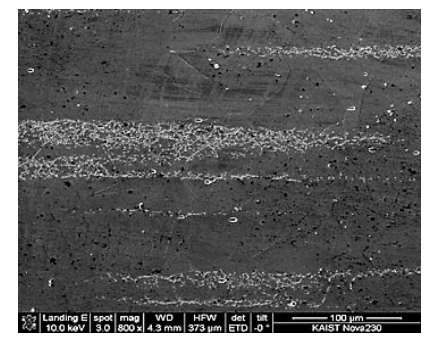

d

Fig. 1. a-optical micrograph; b-SEM micrograph in as a hot rolled condition of steel sample A; c-optical micrograph; d-SEM micrograph in as a hot rolled condition of steel sample B

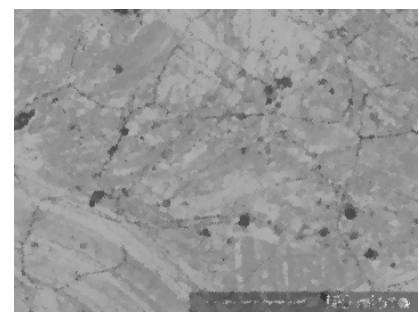

a

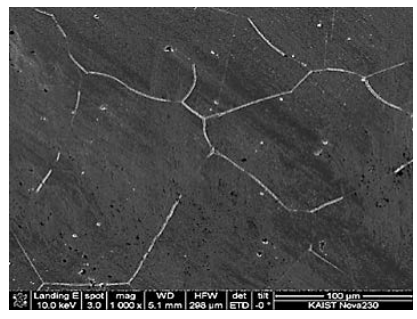

b

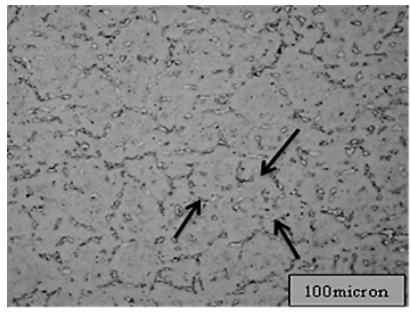

C

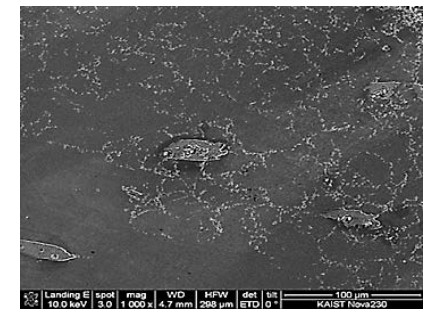

d

Fig. 2. a-optical micrograph;b-SEM micrograph heat-treated at $800^{\circ} \mathrm{C}$ for 1 hour of steel A; c-optical micrograph; d-SEM micrograph heat-treated at $800{ }^{\circ} \mathrm{C}$ for 1 hour steel B 


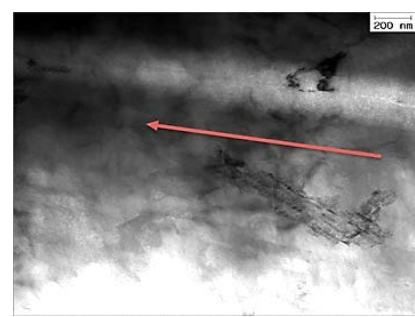

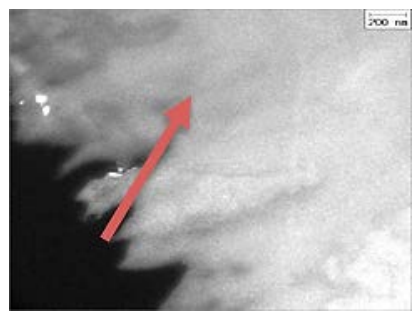

b

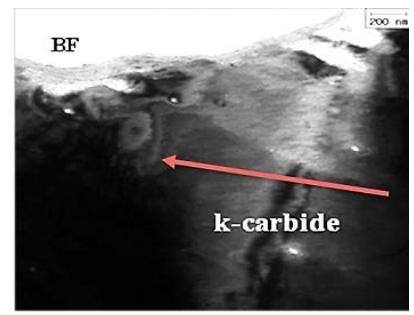

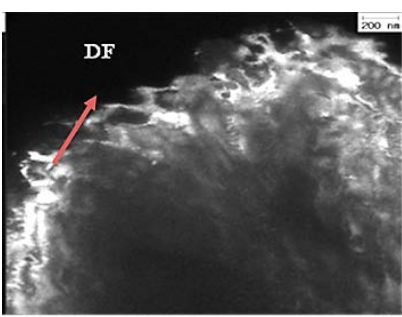

Fig. 3. a, b-TEM images doe not show k carbides in both bright and dark field of steel A; c, d-TEM images of k carbides in both bright and dark field of steel B

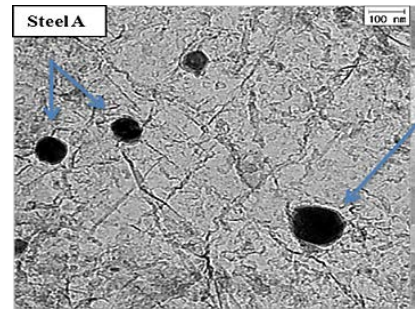

a

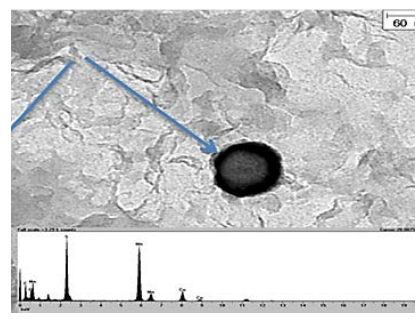

b

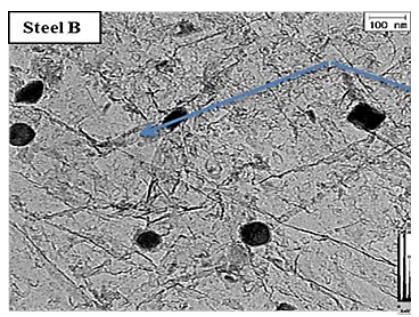

C

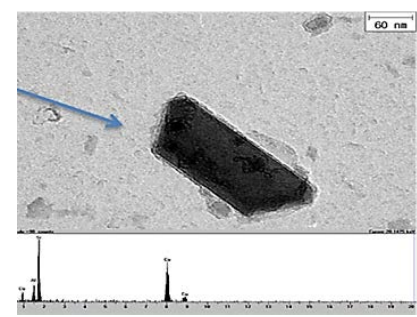

d

Fig. 4. a, b-TEM images do not shows the presence of any nitride particles; c, d-the images clearly showing particles morphology in the presence of AlN nanoparticles

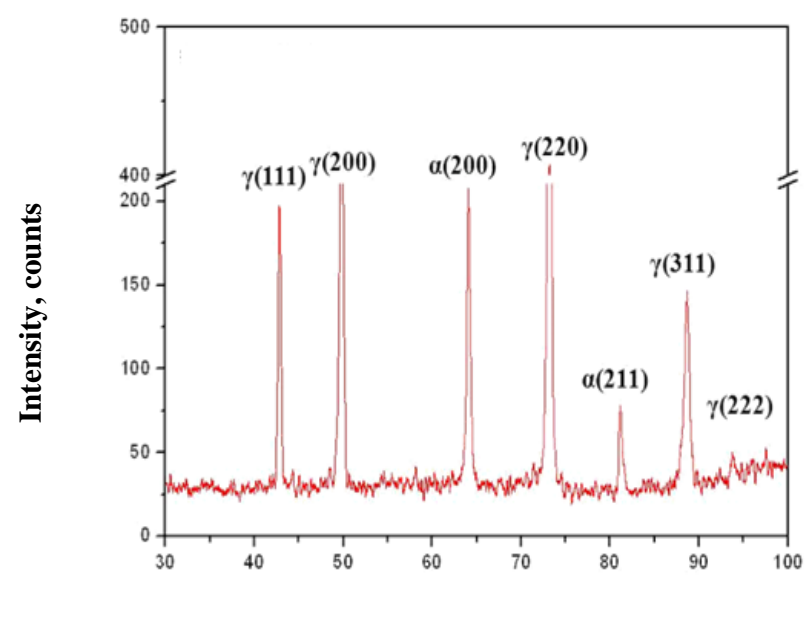

2-theta degree

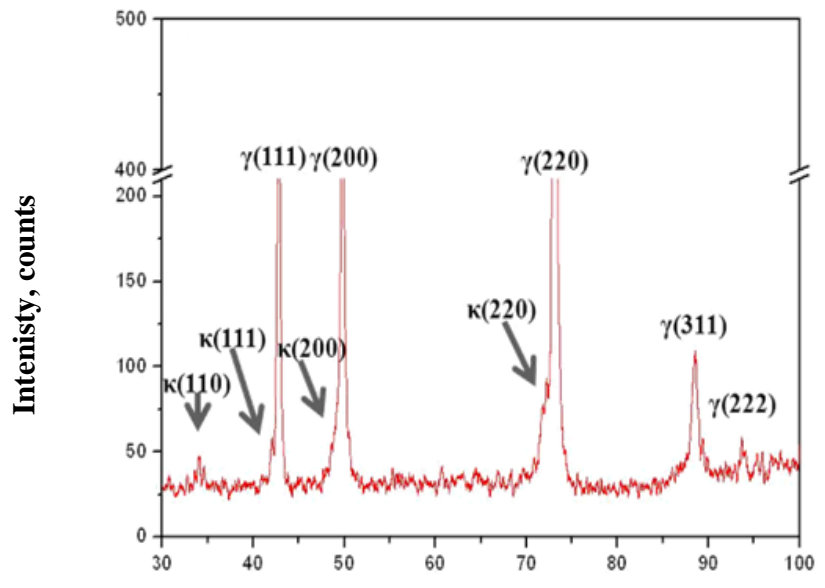

2-theta degree

$\mathrm{b}$

Fig. 5. $a$-the XRD peaks of steel A without aluminum addition does not have k-carbide peaks; b-the XRD peaks of steel B having aluminum addition clearly shows the k-carbide peaks

For further confirmation and observation of forming of $\mathrm{k}$-carbides in the aluminum contained steel and without aluminum contained steel in heat treated condition, XRD was performed to observe the peaks as created by means of interaction of secondary electrons within the atomic level in both experimental steel samples.

Even in heat treated conditions steel A has only alpha and gamma peaks but there are no kappa carbide peaks but in steel B, there is a clear indication of three-phase $(\alpha+\Upsilon+K)$ as shown in Fig. 5 a and b respectively.

After addition of aluminum and presence of nitride particles in steel B proved to be the main reason for forming the kappa carbides, TEM in conjunction with EDS were taken immediately after XRD analysis.

The images and morphology of the nanoparticles are shown in Fig. 4. The arrow indicates the morphology of AlN particles in Fig. 4 c and d that appears as rectangular geometry while the morphology of particles is round shaped in steel $\mathrm{A}$ as is shown in Fig. $4 \mathrm{a}$ and $\mathrm{b}$ and it does not show the morphology of AIN particles, also the EDS results satisfies the same.

\section{RESULTS AND DISCUSION}

Influence of aluminum addition with nitrogen on $\mathrm{k}$ carbide formation in C-Mn steel was investigated. Two steel samples A and B were chosen with and without aluminum in their chemical composition to clearly observe the effect on formation of kappa carbides $[10,11]$. In steel B the presence of aluminum in conjunction with nitrogen forms the small nitride particles that played a crucial role in formation of k-carbide particles which were distributed the entire matrix and as a result fine grain structure formed 
$[1,5,6]$. Microstructure and morphology were revealed by using the research instruments such as (OM) optical microscope, (SEM) scanning electron microscope and (TEM) transmission electron microscope, (EDS) energy dispersive spectrometer [32-34]. It is therefore concluded that AIN particles promote the formation of kappa carbides and the combine effect of AIN particles and Kappa carbide particles microstructure becomes finer.

\section{CONCLUSIONS}

Morphology of kappa carbide formation was investigated in this research work by various experimental techniques and it was found that addition of aluminum has profound effect on formation of kappa carbide in the experimental steel. The previous studies showed that effect of adding aluminum to steel can promote only the formation of aluminum nitride particles that are known as AIN particles but in this present work it was revealed that aluminum does not only promote the formation of AlN particles but also take part in formation of kappa carbides. Therefore, it is concluded that this work supports the previous work done in this area.

\section{Acknowledgments}

Authors of this manuscript are so grateful to department of Materials and Metallurgical engineering NED University of Engineering and Technology Pakistan and KAIST South Korea for their experimental and financial support.

\section{REFERENCES}

1. Cheng, W., Cheng, C., Hsu, C., Laughlin, D. Phase Transformation of the L12 Phase to Kappa-Carbide after Spinodal Decomposition and Ordering in an Fe-C-Mn-Al Austenitic steel Journal of Materials Science and Engineering: A 642 2015: pp. 128-135. https://doi.org/10.1016/j.msea.2015.06.096

2. Li, T., Wang, F., Li, C., Zhang, G., Meng, Q. Carbide evolution in High Molybdenum Nb-Microalloyed H13 Steel During Annealing Process Journal of Iron and Steel Research International 22 (4) 2015: pp. 330-336. https://doi.org/10.1016/S1006-706X(15)30008-X

3. Brasche, F., $\quad$ Haase, C., $\quad$ Chwałek, M., $\quad$ Mayerc, J., Molodov D. Combined $\kappa$-carbide Precipitation and Recovery Enables Ultra-high Strength and Ductility in Light-weight Steels Journal of Materials Science and Engineering: A 795 2020: pp. 139928. https://doi.org/10.1016/j.msea.2020.139928

4. Jeong, S., Kim, B., Moon, J., Park, S., Lee, C. Influence of $\kappa$-carbide Precipitation on the Microstructure and Mechanical Properties in the Weld Heat-affected Zone in Various FeMnAlC Alloys Journal of Materials Science and Engineering: 726 2018: pp. 223-230. https://doi.org/10.1016/j.msea.2018.04.088

5. Li, H., Jian, Z., Feng, G., Feng, Q., Zhan, D. Aging Precipitation Behavior of 18Cr-16Mn-2Mo-1. 1N, High Nitrogen Austenitic Stainless Steel and Its Influences on Mechanical Properties Journal of Iron and Steel Research International 19 (8) 2012: pp. 43-51. https://doi.org/10.1016/S1006-706X(12)60138-1

6. Chen, P., Li, X., Yi, H. Influence of Inter/intra-granular $\kappa$ carbides on the Deformation Mechanism in Lightweight Fe-
20Mn-11.5 Al-1.2 C Steel Materials Characterization 161 2020: pp. 110142.

https://doi.org/10.1016/j.matchar.2020.110142

7. Kim, C., Terner, M., Lee, J., Hong, H., Moon, J., Park, S., Jang, J., Lee, C., Lee, B., Lee, Y. Partitioning of C into $\kappa$ carbides by $\mathrm{Si}$ addition and its effect on the initial deformation mechanism of Fe-Mn-Al-C lightweight steels Journal of Alloys and Compounds 775 2019: pp. 554-564. https://doi.org/10.1016/j.jallcom.2018.10.104

8. Kim, C., Terner, M., Hong, H., Lee, C., Park, S., Moon, J. Influence of Inter/intra-granular $\kappa$-carbides on the Deformation Mechanism in Lightweight Fe-20Mn-11.5 Al1.2 C Steel Materials Characterization 161 2020: pp. 110142.

https://doi.org/10.1016/j.matchar.2020.110142

9. Wang, J., Xing, X., Zhou, Y., Liu, S., Qi, X., Yang, Q. Formation Mechanism of Ultrafine M7C3 Carbide in a Hypereutectic Fe-25Cr-4C-0.5 Ti-0.5 Nb-0.2 N-2LaAlO3 Hard Facing Alloy Layer Journal of Materials Research and Technology 9 (4) 2020: pp. 7711-7720. https://doi.org/10.1016/j.jmrt.2020.05.039

10. Abro, S., Moria, H., Chandio, A., Khazaal, A. Understanding the Effect of Aluminum Addition on the Forming of Second Phase Particles on Grain Growth of Micro-Alloyed Steel Journal of Engineering, Technology \& Applied Science Research 10 (1) 2020: pp. 5153-5156.

11. Abro, S., Siddiqui, M., Siddiqui, H., Chandio, A. Impact of Nano sized Aluminum Nitride Second Phase Particles on Gamma and Alpha Phase Transformation in Less Carbon added Manganese Steel Pakistan Journal of Engineering and Applied Sciences 27 (2) 2020: pp.85-92.

12. Abro, S., Chandio, A., Siddiqui, A., Channa, I. Aluminum and Aluminum Nitrides Effect on Nucleation Sites in Microalloyed Steel Proceedings of the Pakistan Academy of Sciences: A. Physical and Computational Sciences 56 (3) 2019: pp. 17-26.

13. Liu, D., Dinga, H., Hua, X., Han, D., Cai, M. Dynamic Recrystallization and Precipitation Behaviors during Hot Deformation of a $\kappa$-carbide-bearing Multiphase Fe-11Mn10Al-0.9C Lightweight Steel Materials Science and Engineering: A 772 2020: p. 138682. https://doi.org/10.1016/j.msea.2019.138682

14. Zhang, L., Radiguet, B., Todeschini, P., Domain, C., Shen, Y., Pareige, P. Investigation of Solute Segregation Behavior Using a Correlative EBSD/TKD/APT Methodology in a 16MND5 Weld Journal of Nuclear Materials 523 2019: pp. $434-443$. https://doi.org/10.1016/j.jnucmat.2019.06.002

15. Wang, Z., Song, M., Sun, C., He, Y. Effects of Particle Size and Distribution on the Mechanical Properties of $\mathrm{SiC}$ Reinforced Al-Cu Alloy Composites Materials Science and Engineering: A 528 (3) 2011: pp. 1131-1137. https://doi.org/10.1016/j.msea.2010.11.028

16. Kim, H., Suh, D., Kim, N. Fe-Al-Mn-C Lightweight Structural Alloys: A Review on the Microstructures and Mechanical Properties Science and Technology of Advanced Materials 14 (1) 2013: pp. 01-11. https://doi.org/10.1088/1468-6996/14/1/014205

17. Liu, W., Cao, Y., Guo, Y., Xu, B., Sun, M., Li D. Characteristics and Transformation of Primary Carbides during Austenitization in Cr4Mo4V Bearing Steel Materials Characterization 2020: pp. 110636. https://doi.org/10.1016/j.matchar.2020.110636

18. Chandio, A., $\quad$ Abro, S., $\quad$ Rasheed, A., Zehra, K., Ansari, M., $\quad$ Salman, W., $\quad$ Moria, H. $\quad$ Processing, 
Characterisation and Application of Graphene Sindh University Research Journal (Science Series) $52(2)$ 2020: p. 173-180.

19. Chandio, A., Abro, S., Shaikh, A., Ahmed, H., Farooqi, B., Mahmood, F., Yousra, K., Sohail, A. Effect of Concrete Admixtures on Structural Properties and Corrosion Resistance of Steel Reinforcements Materials Science 24 (4) 2021: pp. 547-555. https://doi.org/10.5755/j02.ms.26369

20. Shoaib, M., Naz, A., Faisal Osra, F., Abro, S., Qazi, S., Siddiqui, F., Shah, M., Mirza, A. Green Synthesis and Characterization of Silver-entecavir Nanoparticles with Stability Determination Arabian Journal of Chemistry 14 (3) 2021: pp. 102974. https://doi.org/10.1016/j.arabjc.2020.102974

21. Abro, S. Effect of Niobium and Titanium Addition on Formation of Second Phase Particles in CHQ Steel Using Transmission Electron Microscope Mehran University Research Journal of Engineering and Technology 40 (1) 2021: pp. 31-37. https://doi.org/10.22581/muet1982.2101.03

22. Chandio, A., Shah, A., Channa, I., Abro, S., Rizwan, R., Ali, M., Iqbal, K., Ansari, M., Salman, W. Variation in Mechanical Properties of SAE 1006 Interstitial Free (IF) Steel Sheets During Cold Rolling NUST Journal of Engineering Sciences 13 (2) 2020: pp. 74-80. https://doi.org/10.24949/njes.v13i2.623

23. Abro, S., Alghamdi, M., Moria, H. Nano Particles Effect on Transformation Behavior and Mechanical Properties on Commercial Steel Used for Automobile Parts NUST Journal of Engineering Sciences 13 (2) 2020: pp. 58-62. https://doi.org/10.24949/njes.v13i2.622

24. Abro, S., Moria, H., Alghamdi, M., Khazaal, A., Haque, S. Development and Characterization of Antibacterial Activated Carbon Composite of Zinc and Oxide for Water Filtration as an Industrial Application Pakistan Journal of Scientific \& Industrial Research Series A: Physical Sciences 63 (3) 2020: pp. 162-167.

25. Mehdi, M., $\quad$ Akhtar, M., $\quad$ Abro, S., $\quad$ Qamar, Z., Nauman, M., $\quad$ Aziz, S., $\quad$ Khan, Z., $\quad$ Sufiyan, M., Waseem, M., Azraf, A. Electrochemical Synthesis of AgNP and Mechanical Performance of AgNP-EG Coatings on Soft Elastomer Journal of Elastomers \& Plastics 52 (7) 2020: pp. 609-619.

https://doi.org/10.1177/0095244319879973

26. Abro, S., Chandio, A., Channa, I., Alaboodi, A. Design, Development and Characterization of Graphene Sand Nano-
Composite for Water Filtration Pakistan Journal of Scientific \& Industrial Research Series A: Physical Sciences 63 (2) 2020: pp. 118-122.

27. Abro, S., Hanif, M., Kandhro, F. On the Effect of $\gamma$-phase Transformation Kinetics upon Microstructure Response of Cold Heading Quality Steel NUST Journal of Engineering Sciences $11(2)$ 2020: pp. 51-55. https://doi.org/10.24949/njes.v11i2.399

28. Abro, S., Hussain, F., Sohail, M., Tariq, D., Jawed, K., Sanwal, R., Alghamdi, M. Development and Synthesis of Composite Electrode (rGO/G/PANI) for Capacitor from Burnout Battery Powder: Composite Electrode (rGO/G/PANI) for Capacitor Proceedings of the Pakistan Academy of Sciences: A. Physical and Computational Sciences 57 (2) 2020: pp. 41-50.

29. Abro, S., Shah, A., Alaboodi, A., Shoaib, T. Ageing Analysis of Power Cables Used in Nuclear Power Plants Mehran University Research Journal of Engineering \& Technology 39 (1) 2020: pp. 195-204. https://doi.org/10.22581/muet1982

30. Abro, S., Chandio, A., Channa, I., Alaboodi, A. Role of Automotive Industry in Global Warming Pakistan Journal of Scientific \& Industrial Research Series A: Physical Sciences 62 (3) 2019: pp. 197-201.

31. Abro, S. Role of Mn Atoms on Tensile Properties of Light Weight CHQ Steel Journal of Engineering and applied Sciences 38 (1) 2019: pp. 69-74. https://doi.org/10.25211/JEAS.V38I1.2897

32. Abro, S., Chandio, A., Siddiqui, M., Iftikhar, I. Aluminum and Aluminum Nitrides Effect on Nucleation Sites in Microalloyed Steel Proceedings of the Pakistan Academy of Sciences: A. Physical and Computational Sciences 56 (3) 2019: pp. 17-26.

33. Abro, S., $\quad$ Alghamdi, M., $\quad$ Hanif, M., $\quad$ Moria, $\mathbf{H}$. Microstructure Integration upon Heating Temperatures in low Carbon Mn Seel Journal of Engineering and Applied Sciences 39 (2) 2021: pp. 164-169. https://doi.org/10.17582/journal.jeas/39.2.164.169

34. Abro, S., Chandio, A., Aftab, U. Effect of Heating Rate on Microstructural Developments in Cold Heading Quality Steel Used for Automotive Applications Mehran University Research Journal of Engineering and Technology 37 (3) 2018: pp. $461-466$.

(c) Abro et al. 2022 Open Access This article is distributed under the terms of the Creative Commons Attribution 4.0 International License (http://creativecommons.org/licenses/by/4.0/), which permits unrestricted use, distribution, and reproduction in any medium, provided you give appropriate credit to the original author(s) and the source, provide a link to the Creative Commons license, and indicate if changes were made. 